\title{
ALIEN INHERITANCE STATUTES AND THE FOREIGN RELATIONS POWER
}

\author{
State alien inheritance statutes of the "benefit" or "reciprocity" \\ type have provided the states with a means of attempting to \\ influence the inheritance laws of foreign nations, and have been \\ utilized by some state judges to express disapproval of particular \\ foreign governments. This note analyzes the potential conflict \\ between these statutes and the exclusive federal foreign relations \\ power in light of a recent Supreme Court decision finding an \\ alien inheritance statute to be an unconstitutional interference \\ with federal authority.
}

While abrogating the common law rule that absolutely proscribed inheritance of real and personal property by non-resident aliens, ' a substantial number of American states" have enacted either "benefit" or "reciprocity" regulations which provide for alien inheritance only if certain requirements are met. Reciprocity statutes allow inheritance only if it is shown that the foreign country in which the heir is a citizen allows an American heir to inherit property within its borders upon the same terms as citizens of that country inherit property. ${ }^{3}$ Such

\footnotetext{
'At common law an alien could acquire realty by purchase but not by devise or intestate succession and, even in the former situation, could not hold land against the king. 2 Blackstone. Commentaries 293: Fairfax's Devisee v. Hunter's Lessee, 11 U.S. (7 Cranch) 603 (1813). See generally. Boyd, Treaties Governing the Succession to Real Property by Aliens, 51 MiCH. L. REv. 1001, 1001-05 (1953). The common-law disabilities have been repealed altogether in some states and modified by the statute in all others. See Sullivan, Alien Land Laws: $A$ Reevaluation, 36 TEMP. L.Q. 15 (1962).

: Well over one third of the states háve enacted some form of alien inheritance statute. See notes 3 \& 5 infra.

'Section 259 of the California Probate Code, the prototype of the reciprocal rights restriction, provides: "The right of aliens not residing within the United States to take real [and personal] property in this State by succession or testamentary disposition . . . is dependent in each case upon the existence of a reciprocal right upon the part of citizens of the United States to take real [and personal] property upon the same terms and conditions as residents and citizens of the respective countries of which such aliens are residents. . . " CAL. PROB. CODE $\$ 259$ (West 1956). For similar enactments in other states, see ARIZ. Rev. STAT. ANN. \& 14-2 I2(c) (1956); lowa Code $\S 567.8$ (Supp. 1966); MoNt. Rev. Codes ANN. $\$ 91-520$ (1964); Nev. Rev. Stat. \$§ 134.230-.250 (1966); N.C. GeN. Stat. \$ 64-3 (1966); OKLa. Stat. tit. 60, § 121 (1963); Ore. Rev. Stat. \& 111.070 (1967); Wyo. Stat. Ans. 2-43.1 (Supp. 1967). See generally Note, State Statutes A ffecting the Inheritance and Distribution of Estates to Foreign Herrs, 1967 U. ILL. L.F. 141, 142-43.
} 
statutes commonly provide for escheat to the state if the alien heir cannot sustain the burden of showing reciprocity and if there are no other domestic heirs. ${ }^{+}$Benefit statutes typically provide that a nonresident alien must show that he will be able to enjoy the benefit, use and control of the inheritance before the probate court will release it to him..$^{5}$ Unlike the reciprocity statutes, these regulations are not confiscatory since if the heir cannot sustain the burden of proof, ${ }^{6}$ the inheritance is paid into the court until such time as the heir can establish that he will receive the benefit of inheritance." The state enactments which presume to govern the property rights of foreign nationals have long been recognized as creating a potential federalistic conflict between the states' governmental interest in and power over the devolution of property within their boundaries and the national government's power in the ill-defined area of foreign relations. ${ }^{8}$ The

\footnotetext{
*E.g., CAL. Prob. Code $\S 259.1$ (West, 1967 Supp.): "The burden shall be upon nonresident aliens to establish the existence of the reciprocal rights . . . " See In re Bevilacqua's Estate, 31 Cal. 2d 580, 591 P.2d 752 (1948) ( $\$ 259.1$ held not invalid as arbitrary). Reciprocity statutes further typically provide that "[i]f such reciprocal rights are not found to exist and if no heirs other than such aliens are found eligible to take such property, the property shall be disposed of as escheated property." CAL. PROB. CODE $\S 259.2$ (West 1956).

For the burden of proof provision of the Oregon statute, see note 51 in/ra.

"Typical of these laws is section 2218-2 of the New York Surrogate Court Procedure Act: "Where it shall appear that a beneficiary would not have the benefit or use or control of the money or other property due him or where other speeial circumstances make it desirable that such payment should be withheld the decree may direct that such money or property be paid into court for the benefit of the beneficiary or the person or persons who may thereafter appear to be entitled thereto. The money or property so paid into court shall be paid out only upon order of the court or pursuant to the order or judgment of a court of competent jurisdiction." N.Y. Surr. CT. Pro. Law $§ 2218-2$ (McKinney Supp. 1968). Other "benefit" statutes are CoNx. Gen. Stat. ANN. \& 45-278 (1960); Fla. Stat. ANN. § 731.28 (1964); Md. ANN. Code art. 93, § 161 (1963); Mass. ANn Laws ch. 206, § 27A (Supp. 1966); Mich. Stat. ANN. § 27.3178 (306a) (1962); N.J. Rev. Stat. § 3A:25-10 (1953); Ohlo Rev. Code ANN. $\S \S 2113.81-83$ (Page Supp. 1962); PA. Stat. ANN. tit. 30, $\$ 320.737,1156$ (Supp. 1966); R.I. GEN. LAwS ANN. § 33-13-13 (1956).

${ }^{6}$ E.g., N.Y Surr. CT. Pro. Law $\$ 2218-3$ (McKinney Supp. 1968): "In any such proceeding where it is uncertain that an alien beneficiary or fiduciary. . . Would have the benefit or use or control of the money or property due him the burden of proving that the alien beneficiary will receive the benefit or use or control of the money or property due him shall be upon him or the person claiming from, through or under him."

${ }^{7}$ See note 5 supra.

'See Boyd, The Invalidity of State Statutes Governing the Share of .Vonresidem Aliens in Decedents' Estates. 51 GEO. L.J. 470, 492-500 (1963); Comment, State Reciprocity Statuten and the Inheritance Rights of Nonresident Aliens, 1963 Duke L.J. 315, 316; Comment, Right of Non-Resident Alien to Take Real and Personal Property. 25 So. CAL. L. Rev. 329 (1952); Comment, State Regulation on Nonresident Alien Inheritance-An Anonoly in Foreign
} 
United States Supreme Court, in its recent decision of Zschernig $v$. Miller, ${ }^{9}$ has considered the conflict and attempted to set forth new guides for its resolution.

State alien inheritance statutes were first challenged as unconstitutional infringements upon the exclusive power of the federal government over foreign affairs in Clark v. Allen. ${ }^{10}$ In that case the petitioners contended that the promotion of the rights of American citizens to inherit abroad by offering to aliens reciprocal rights of inheritance in California was a matter for settlement solely by the federal government on a nation-wide basis. "In summarily rejecting this argument as "farfetched"' 2 and in sustaining the constitutionality of the statute, the Court stated that devolution rights are determined by state law in the absence of an overriding federal policy such as a treaty requiring a given disposition of property. ${ }^{13}$ Since there were no

Policy. 18 U. CHI. L. Rev. 329 (1951); Note, State Statutes Affecting the Inheritance and Distribution of Estates to Foreign Heirs, 1967 U. ILL. L.F. 141, 148-49.

- 389 U.S. 429 (1968).

${ }^{10} 33$ I U.S. 503 (1947). Clark involved a trio of claimants to the estate of a California testatrix: (1) the German beneficiaries under the will who claimed the right to inherit both real and personal property by virtue of Article IV of the Treaty of Friendship. Commerce and Consular Rights with Germany, December 8, 1923, art. IV, 44 Stat. 2132, T.S. No. 725, see note $14 \mathrm{infra}$; (2) the California heirs at law of the testatrix who argued that the treaty had been abrogated by a state of war between the signatories, and further that, since Germany did not grant reciprocal inheritance rights to A mericans, the estate should vest in them by virtue of the California reciprocity statute, see note 3 supra; and (3) the federal Alien Property Custodian whose claim to the estate was based on the Trading with the Enemy Act of 1917, 50 U.S.C. Appendix $\S 6$ (1964). See Crowley v. Allen, 52 F. Supp. 850 (N.D. Cal. 1943).

Regarding the applicability of California's reciprocity statute, the District Court accepted the German heirs' argument that the statute was unconstitutional because its legislative history. indicated a "design ... to fix a policy of international relations, which, the [California] L.egislature thought, would aid the United States in anticipated hostilities with a foreign government." Crowley v. Allen, 52 F. Supp. 850, $853-54$ (N.D. Cal. 1943). The Ninth Circuit held it improper to rely on legislative motive in order to determine the constitutionality of state legislation, Allen v. Markham, I56 F.2d 653, 660 (9th Cir. 1946), and before the U.S. Supreme Court the heirs apparently abandoned the argument based on legislative motive, contending instead that any state offer of reciprocal rights to foreign nationals was an infringement on the exclusive federal power over foreign affairs. See Zschernig v. Miller, 389 U.S. 429, 433 n.5 (1968); Clark v. Allen, 331 U.S. 503, 516 (1947).

"331 U.S. at 516-17.

12 Jd. at 517.

"13 "Rights of succession to property are determined by local law. See Lyeth v. Hoey. 305 U.S. 188, 193; Irving Trust Co. v. Day, 314 U.S. 556, 562. Those rights may be affected by an overriding federal policy, as where a treaty makes different or conflicting arrangements." Id. at 517. But see text at notes 17-25 infra. 
applicable treaty provisions to control succession to personal property in this case, the Court found no need for state law to yield with regard to personalty. ${ }^{14}$ Moreover, the Court stated that the statute had not entered the prohibited area of negotiating or making a compact with a foreign nation. Finally, the Court concluded that the state law did not "cross the forbidden line" and interfere with the federal government's domain over foreign relations since any effect such alien inheritance legislation might have in foreign countries would be merely "incidental or indirect."'s

The Clark decision may be criticized as extending undue deference to the states' interest in the regulation of inheritance by aliens, while underestimating the effects of such regulation upon foreign relations, ${ }^{16}$ since the Court implied that, in the absence of overt state negotiation with a foreign nation, only a clearly defined federal policy, such as one embodied in a treaty, could restrict state laws regarding devolution. ${ }^{17}$ State property and inheritance laws, like any other state action, are subject to applicable Constitutional limitations and, thus, may be

\footnotetext{
"Clark also involved the Treaty of Friendship, Commerce and Consular Rights with Germany, December 8, 1923, art. IV, 44 Stat. 2132, T.S. No. 725. The Court held that the provision of the treaty allowing aliens to dispose of realty which, under local law, their alienage would prevent them from holding was not incompatible with national poliey in time of war. 331 U.S. at 514 . However, as construed by the Court, the treaty did not cover personal property located within the United States which an American national undertakes to leave to German nationals. Id. at 516.

is Id. at 517.

${ }^{16}$ See, e.g., Boyd, supra note 8, at 493; Moore, Federalism and Foreign Relations, 1965 DukE L.J. 248, 309-10.

${ }^{17}$ See text at notes 10-15 supra. The Court had previously indicated that the state's power regarding the testamentary disposition of property was virtually absolute. In Irving Trust Co. $v$. Day, 314 U.S. 556, 562 (1942), the Court said: "Nothing in the Federal Constitution forbids the legislature of a state to limit, condition, or even abolish the power of testamentary disposition over property within its jurisdiction." See United States v. Fox, 94 U.S. 315,320 (1876): Mager v. Grima, 49 U.S. (8 How.) 490 (1850); cf. United States v. Burnison, 339 U.S. 87, 93 (1950); Maxwell v. Bugbee, 250 U.S. 525, 54 I-42 (1919). Taken out of context, the Court's statement suggests that the states possess unbridled discretion regarding the privilege of testamentary disposition. That Irving Trust does not stand for so broad a proposition is demonstrated by the very issue scrutinized in that case-whether, consistent with due proeess and the contract clause of the Constitution, New York could annex a wife's right of election to the privilege of exccuting a will. Probably a more accurate statement of the scope of state power is found in Mager $v$. Grima, supra: "II] a state may deny [inheritance to aliens] altogether, it follows that, when it grants it, it may annex to the grant any conditions which it supposes to be required by its interests or policy." 49 U.S. (8 How.) at 493 (emphasis added). Moreover, in none of these cases was there a question whether state regulation of succession must yield to conflicting federal action based upon one of the delegated powers of the national government. See note 18 infra.
} 
preempted by conflicting federal action taken pursuant to one of the delegated powers of the national government. In the past, the Supreme Court has sustained the preemption of such state regulation by both statute ${ }^{18}$ and treaty..$^{19}$ Similarly, the due process clause has been frequently invoked to challenge statutory modifications of the estate system, ${ }^{20}$ and the equal protection clause has been held to preclude the application of a state alien land law in circumstances in which it would be racially discriminatory. ${ }^{21}$ Moreover, the federal

13 Where Congress has legislated régarding property devolution, the Court has seen little difficulty sustaining this action, even though it partially preempted existing state statutes. A United States statute provides that when a veteran dies intestate and without legal heirs in a veteran's hospital, his personal property "shall immediately vest in and become the property of the United States as trustee for the sole use and benefit of the General Post Fund. . . ." 38 U.S.C. $\S 5220$ (1964). The Court sustained this provision on the ground that the powers to raise armies and navies and to conduct war permit Congress to legislate as to veterans, saying: "The fact that this law pertains to the devolution of property does not render it invalid. Although it is true that this is an area normally left to the States, it is not immune under the Tenth Amendment from laws passed by the Federal Government which are, as is the law here, necessary and proper to the exercise of a delegated power." United States v. Oregon, 366 U.S. 643,649 (196I).

19 E.g., Kolovrat v. Oregon, 366 U.S. 187 (1961); Clark v. Allen, 331 U.S. 503 (1947); Geofroy v. Riggs, 133 U.S. 258, 267 (1889); Hauenstein v. Lynham, 100 U.S. 483, 488-90 (1879).

The regulation of inheritance by nonresident aliens has frequently been a provision in American treaties. See Boyd, supra note 1, at 1006-07, 1009-13; Meekison, Treaty Provisions for the Inheritance of Personal Property, 44 AM. J. INT'L L. 313, 314 \& nn. 5-26 (1950); Note. U. Citl. L. Rev. 315, 321 \& n. 41 (1949). With respect to realty, American treaties have generally granted aliens only a qualified right of succession. In the event alienage is a bar to succession under state law, the standard American treaty formula guarantees nonresident and resident aliens the right to sell their shares in any decedent's real property located in the United States within a specified period of time. See Boyd, supra, at 1009-19. By contrast a number of treaties have stipulated that if an alien dies owning personalty in the United States, his beneficiaries, regardless of nationality, are entitled to the personality without any limitations. See Meekison, supra. Under present treaty practice, aliens are granted the same right of sale for both realty and personalty. E.g., Treaty of Friendship and Commerce with Pakistan, Nov. 12, 1959, [1961] 12 U.S.T. 110,115 (art. 9. para. 2), T.1.A.S. No. 4683; Treaty of Friendship, Commerce and Navigation with Nicaragua, Jan. 21, 1956. [1958] 9 U.S.T. 449, 456-57 (art. 9 , para. 2), T.I.A.S. No. 4024 .

:0 See, e.g., Irving Trust Co. v. Day, 3 I4 U.S. 556 (1941); Opinion of the Justices, 337 Mass. 786, 151 N.E.2d 475 (1958). See also Legislative Research Center, U. of Mich. Law Scilool, Current Trends in State Legislation, 1953-1954 at 625-38 (1955).

"Oyama v. California, 332 U.S. 633 (1947). Undoubtedly the constitutional guarantees of due process and equal protection of the laws are fully available to resident aliens. E.g.. Oyama v. California, 332 U.S. 633 (1947); Home Ins. Co. v. Dick, 281 U.S. 397, 411 (1930) (fourteenth amendment "extends to aliens"); Truax v. Raich, 239 U.S. 33 (1915); Yick Wo v. Hopkins, 118 U.S. 356 (1886). See also 3 G. HACKWORTH, DigeST OF INTERNATIONAL LAW 279 (1942); Boyd, supra note 8, at 481-92; Comment, The Alien and the Constitution. 20 U. CHI. L. REv. 547, 564- 
power over foreign affairs has traditionally been accorded a special status under the Constitution ${ }^{22}$ since the need for uniformity in dealing

69 (1953). However, the applicability of these guarantees to nonresident aliens is somewhat problematical. The due process clause has, by its terms, no jurisdictional limitation and could be invoked to protect the vested property rights of nonresident aliens against an unreasonable taking by a state. See Boyd, supra note 8 , at 482-85 \& n.63. Since the fourteenth amendment's equal protection clause is limited to "any person within [the state's] jurisdiction," it is doubtful that a nonresident alien could utilize this guarantee. See Blake v. McClung, 172 U.S. 239, 26061 (1898) (dictum); Yick Wo v. Hopkins, 118 U.S. 356, 369 (1886) (dictum). Recent commentators have contended that a territorial construction is too narrow, suggesting that ownership of property within the state or "legislative jurisdiction" involving certain minimal contacts with a state would be more realistic standards for invoking the equal protection guarantee. Currie \& Schreter, Unconstitutional Discrimination in the Conflict of Laws: Equal Protection, 28 U. CHI. L. Rev. I, 5-10 (1960); Note, Property Rights of . Aliens under lowa and Federal Law, 47 lowa L. Rev. 105, 114-15 (1961).

"For example, the power to expel undesirable aliens, Fong Yue Ting v. United States, 149 U.S. 698 (1893), the power to acquire territory by discovery and occupation, Jones v. United States, 137 U.S. 202 (1890), and the power to make such international agreements as do not constitute treaties in the constitutional sense, United States v. Belmont, 301 U.S. 324 (1937), have been sustained as valid exercises of the federal foreign affairs power.

Although it is generally believed that the federal foreign relations power is exclusive, see note 24 infra, the source of the power has been the subject of some debate. One school of thought maintains that national sovereignty supports the exercise of national power in the international sphere without the necessity of a specific constitutional referrent for the action. This theory received its fullest judicial explication by Justice Sutherland in United States v. Curtiss-Wright Export Corp., 299 U.S. 304 (1936): "As a result of the separation from Great Britain by the colonies acting as a unit, the powers of external sovereignty passed from the Crown not to the colonies severally, but to the colonies in their collective and corporate capacity as the United States of America. . . . The Union existed before the Constitution, which was ordained and established among other things to form 'a more perfect Union.' Prior to that event, it is clear that the Union, declared by the Articles of Confederation to be 'perpetual,' was the sole possessor of external sovereignty. . . . It results that the investment of the federal government with the powers of external sovereignty did not depend upon the affirmative grants of the Constitution. The powers to declare and wage war, to conclude peace, to make treaties, to maintain diplomatic relations with other sovereignties, if they had never been mentioned in the Constitution, would have vested in the federal government as necessary concomitants of nationality." Id. at 316-18. See also Fong Yue Ting v. United States, 149 U.S. 698 (1893) (Field, J.) (dictum); The Chinese Exclusion Cases, 130 U.S. 581 (1889) (Ficld, J.) (dictum); $\%$ Perez v. Brownell, 356 U.S. 44 (1958). See generally E. Corivin, The President: Office and Powers, 1787-1957 at 170-73 (4th ed. 1957). Mr. Justice Sutherland's theory and the historical analysis supporting it have been seriously questioned. See Levitan, The Foreign Relations Powers: An Analysis of Mr. Justice Sutherland's Theory, 55 YALE L.J. 467 (1946).

Arguably, however, the plenary nature of the federal foreign relations power can be implied as a resultant of a group of expressly delegated national powers and prohibitions on state action. U.S. CoNst. art. I, $\$ 8$, cls. 1-3; art. III, $\S 2$, cl. l; art. VI, el. 2. This theory has the virtue of being consistent with the view that our national government is one of delegated powers, and is preferred by most commentators. E.g., Q. IVRIGHT, The Control. Or AMeriCan Foreign Relations 132-34 (1922); Levitan, supra at 493 n.102; Quarles, The Federal Govermment: As to Foreign Affairs, Are Its Powers Inherent as Distinguished Jrom Delegated? 32 GEO. L.J. 375 (1944). 
with international affairs was of prime concern to the framers of the Constitution. ${ }^{23}$ The Supreme Court has frequently maintained that federal authority over matters affecting foreign affairs is exclusive. ${ }^{24}$ Thus, to interpret Clark as ruling that state regulation of succession necessarily has too "indirect" an effect on foreign affairs to be constitutionally unremonstrable would conflict with the Court's tradition of jealousy in guarding the federal government's control over all matters of foreign relations. ${ }^{25}$ Therefore, it may be contended that Clark merely stands for the proposition that a state may establish an inheritance scheme for aliens on a reciprocity basis.

However, encouraged by the broad interpretation of Clark, courts applying alien inheritance statutes seem frequently to have gone beyond the designated statutory considerations of benefit and reciprocal inheritance rights to import foreign policy considerations into the probate proceedings.

"See The Federalist Nos. 3, 4, 5, 22, 42 \& 80. See generally $C$. WARRen, The Making of THE CONSTITLTION (1937).

* See, e.g.. United States v. Pink, 315 U.S. 203, 232 (1942) (dictum), where the Court stated: "Here, we are dealing with an exclusive federal function. If state laws and policies did not yield before the exercise of the external powers of the United States, then our foreign policy might be thwarted." Sec also United States v. Belmont, 301 U.S. 324, 330 (1937). Only once has the Court considered the possibility that the states may have some concurrent power to take action that might affect foreign relations. In Hines v. Davidowitz, 312 U.S. 52 (1940), the Court stated: "[T]his [Congressional] legislation is in a field which affects international relations, the one aspect of our government that from the first has been most generally conceded imperatively to demand broad national authority. Any concurrent state power that may exist is restricted to the narrowest of limits. . . . Id. at 68. Elsewhere the Hines Court noted: "Experience has shown that international controversies of the gravest moment, sometimes even leading to war, may arise frum real or imagined wrongs to another's subjects inflicted, or permitted, by a government." lll. at 64 .

"While the Court has frequently maintained that federal power over foreign affairs is exclusive, see note 24 supra, it is noteworthy that the negative implications of this exclusiveness have never been relied upon to proscribe state activities that might interfere with foreign affairs. Only in Holmes v. Vennison, 39 U.S. (14 Pet.) 540 (1840), can there be found a clearly enunciated judicial exposition of the preemptive effect of the dormant federat foreign relations power. That case presented the question whether the governor of Vermont could constitutionally arrest and extradite a fugitive indicted for murder in Canada. Against a back-drop of U.S.Canadian negotiations over matters which included extradition, Chief Justice Taney reasoned that ad hoc state extraditions would diminish the ability of the federal government to induce neighboring countries to enter into such treaties, and thus that such statc action was repugnant to the constitutionally warranted federat power over international affairs. Id. at 574-75. The Supreme Court, however, not being able to decide on a course of action, finally dismissed the writ of error for want of jurisdiction. $I d$. at 597 ; $c$. Blythe v. Hinckley, 180 U.S. 333, 340 (1901) (U.S. Constitution does not prohibit a state's granting inheritance rights to nonresident aliens). See generally Moore, supra note 16, at 299-311. 
Despite minor variations, ${ }^{26}$ the prevailing statutory scheme of reciprocity which is intended to induce foreign nations to grant inheritance to United States citizens merely requires that the alien heir demonstrate that his foreign nation does not discriminate between its own citizens and Americans in regard to inheritance rights. ${ }^{27}$ Thus, logically the inquiry under a reciprocity statute should focus on the nature of American citizens' inheritance rights under foreign law as compared to the rights of citizens of the foreign country. ${ }^{28}$ This

Perhaps the failure to explore the negative implications of the federal foreign relations power can be explained by the availability of a similar doctrine based on a more explicit Constitutional referrent-the federal power over foreign commerce. U.S. ConST. art. 1. \& 8, cl. 3; Brown v. Maryland, 25 U.S. (12 Wheat.) 419 (1827). Relying largely on such an implied prohibition arising from the foreign commerce clause, the Court has overturned statc statutes which unduly burdened immigration of aliens. See Henderson v. Mayor of New York, 92 U.S. 259 (1875); Chy Lung v. Freeman, 92 U.S. 275 (1875). However, in Mager v. Grima, 49 U.S. (8 How.) 490 (1850), the Court upheld a discriminatory tax on inheritance by nonresident aliens, rejecting the contention that transmission of funds to nonresident aliens was foreign commerce. $/ d$. at 493 . Arguably the more expansive contemporary definition of commerce seriously undercuts the Mager rationale. See, e.g. . Heart of Atlanta Motel, Inc. v. United States, 379 U.S. 241 (1964); Wickard v. Filburn, 317 U.S. 111 (1942).

${ }^{26}$ For decedents dying prior to 1951, an interpretation of an earlier Oregon statute prevented a finding of reciprocity unless the foreign country allowed Americans to inherit in the same manner as an alien would inherit from an Oregon estate. In re Estate of Krachler, 199 Orc. 448. 263 P.2d 769 (1953), construing Ch. 399, $\$ 1$ [1937] ORE. LAws 607. Although it is doubtful if any countries could meet the literal requirements of this test, this law may still have some vitality since the statutory requirements to be considered are those extant at the time of the decedent's death, not at the time of the litigation. Mullart v. State Land Board, 222 Orc. 463, 353 P.2d 531 (1960); Clostermann v. Schmidt, 215 Ore. 55, 332 P.2d 1036 (1958). Moreover, the present Nevada statute contains the same language as the earlier Oregon act. See NEV. REV. STAT. $\S 134.230-.250$ (1966). Since there have been no reported cases under the Nevada statute, it is possible that the Nevada courts may adopt the reciprocity standard of the Oregon court in Krachler.

Under the Arizona and Oklahoma statutes, an alien eligible for citizenship may take and hold real and personal property in the same manner as a United States citizen would under the laws of the alien's native country. ARIZ. REv. STAT. ANN. § 14-212(c) (1956); OKLA. STAT. tit. 60, $\S 121$ (1963).

"All that it [California's reciprocity statute] requires is that there be no discrimination shown in inheritance matters between nationals of that country and residents and citizens of ours." In re Miller's Estate, 104 Cal. App. 2d 1, 12, 230 P.2d 667, 674 (1951). Sec also In re Raihs, 102 Cal. App. 2d 260. 227 P.2d 564 (1951); Corbett v. Stergios, 256 lowa 12. 126 N.W.2d 342 (1964).

"3 It is doubtful, however, that mere abstract lack of discrimination would suffice where the foreign country grants no inheritance rights to either Americans or its own citizens, even though such a country might meet the literal requirements of the reciprocity statute. Anticipating such a situation, the California Supreme Court has indicated that its reciprocity statute "necessarily imports a requirement that the inheritance rights in the foreign country mect some minimum standard of economic substantiality." In re Larkin, 65 Cal. 2d 60, 65, 416 P.2d 473, 476, 52 Cal. Rptr. 441, 442 (1966). 
inquiry is uniformly held to be a question of fact ${ }^{29}$ and generally requires the alien heir to produce expert testimony as to the law of his homeland.$^{30}$ Nevertheless, when the expert testimony involves proof of the law of a Communist nation, the political biases of American judges have frequently combined with the statutory burden of proof to make a finding of reciprocity with a Communist nation a practical impossibility. ${ }^{31}$

Similarly, benefit statutes which are intended to prevent distribution when confiscation by the foreign government is likely, ${ }^{32}$ have been used by the state courts to express tacit hostility to foreign governments. Wide discretion has been invested in the probate courts $\mathrm{s}^{33}$ in applying these statutes and, thus, a great variety of circumstances have been considered relevant in deciding whether or not to allow inheritance by a non-resident alien. First, some courts have strictly interpreted the benefit standard by denying alien inheritance if it is contingently possible that the alien would not receive full benefit, use or control of the property. ${ }^{34}$ Minute inquiries into monetary exchange

iv F..g., In re Schluttig's Estate, 36 Cal. 2d 416, 224 P.2d 695 (1950). Compare In re Miller's Estate, 104 Cal. App. 2d I, 230 P.2d 667 (195I) (reciprocity with Germany found as of April 22, . 1942), with Estate of Thramm, 80 Cal. App. 2d 756, 183 P.2d 97 (1947) (no reciprocity with Germany as of June 3, 1943). See generall! A. F.HRENizweig, A TREATISE ON the Conflict Or LAws $\$ \$ 129 \& 248$ n.39 (1962).

${ }^{30}$ Sec. e.g.. Estate of Larkin, 65 Cal. 2d 60, 416 P.2d 473, 52 Cal. Rptr. 441 (1966); State Land Bd. v. Pekarek, 234 Ore. 74, 378 P.2d 734 (1963). See generall! A. Ehrenzweig. A Treatis: ON THF CoNflict of Laws \$248 (1962); Comment, The Application of the Reciprocal Rights and Benefit Rules to Foreign Legacies. 36 TuL. L. Rev. 799, 81 I (1962).

"See. e.g., State Land Bd. v. Pekarek, 234 Ore. 74, 378 P.2d 734 (1963), where the court said: "Assuming, without deciding, that all of the evidence offered by the legatees was admissible, it can be given relatively little weight. The statements of Czechoslovakian officials must be judged in light of the interest which they had in the acquisition of funds for their government. Moreover, in judging the credibility of these witnesses we are entitled to take into consideration the fact that declarations of government officials in communist-controlled countries as to the state of affairs existing within their borders do not always comport with the actual facts." Id. at 83, 378 P.2d at 738. See notes $44-45$ infra.

"See. e.g., In re Reidl, 23 App. Div. 2d 171, 172, 259 N.Y.S.2d 217, 218 (1965); In re Petroffs Estate, 49 Misc. 2d 233, 236, 267 N.Y.S.2d 8, 11 (Surr. Ct. 1966).

"See statutes cited note 5 supra. In addition to deciding whether an heir will receive the henefit, use or control of property, most courts have the statutory authority to deny distribution "where other special circumstances make it desirable. . . "E.g., N.Y. SuRR. CT. Pro. Law $\S 2218-2$ (McKinney Supp. 1968). While no reported cases have been decided under this clause, its presence emphasizes the permissive character of the statute. Moreover, no special provisions are made for de novo appellate review, and consequently probate judges' findings of fact are virtually never reversed.

"Sce, c.g., In re Braier, 305 N.Y. 148, 111 N.E.2d 424, appeal disnissed sub nom. Kalmane 
rates, ${ }^{35}$ currency revaluations, ${ }^{36}$ and the scope of foreign officials' administrative discretion ${ }^{37}$ have been entertained to deny inheritance. Many courts ${ }^{38}$ have refused distribution on the basis of a Treasury Regulation declaring that federal checks and warrants will not be sent to individuals residing in certain listed countries where "there is not a reasonable assurance that a payee in those areas will actually receive checks or warrants . . . and be able to negotiate the same for full value." 39 Courts applying benefit statutes have examined the status of private property ownership in the foreign country ${ }^{40}$ or the effect of inheritance taxes levied by the foreign country," or simply have taken judicial notice of the economic disabilities in a Communist nation and proceeded no further ${ }^{42}$ Some courts have denied inheritance on the basis of a fear that proceeds from American estates would be used to

v. Green, 346 U.S. 802 (1953); In re Greenberg, 46 Misc. 2d 883, 261 N.Y.S.2d 176 (Surr. Ct. 1939); Wolder's Estate, 28 Pa. D. \& C. 2 d 51 (Orphans' Ct. 1962).

${ }^{35}$ E.g., Petition of Mazurowski, 331 Mass. 33, 38, 116 N.E.2d 854, 858 (1954); In re Shelick's Estate, 50 Misc. 2d 293, 270 N.Y.S.2d 34 (Surr. Ct. 1966). See generally. Berman, Soviet Heirs in American Courts, 62 Colum. L. Rev. 257, 266-68 (1962).

${ }^{36}$ In re Wells, 204 Misc. 975, 980-81, 126 N.Y.S.2d 441, $447-48$ (Surr. Ct. 1953).

"E.g., In re Estate of Feierman, 202 Cal. App. 2d 552, 20 Cal. Rptr. 883 (1962); In re Markewitsh, 62 N.J. Super. 407, 163 A.2d 232 (Passaic County Ct., P. Div. 1960); In re Braier, 305 N.Y. 148, 111 N.E.2d 424, appeal dismissed sub nom. Kalmane v. Green, 346 U.S. 802 (1953). See generally' Bader, Brown \& Grzybowski, Soviet Inheritance Cases in American Courts and the Soviet Property' Regime. 1966 DUKE L.J. 98; Berman, supra note 35, at 273 \& n.43.

"See, e.g., In re Markewitsh, 62 N.J. Super. 407, 163 A.2d 232 (Passaic County Ct., P. Div. 1960); In re Siegler, 284 App. Div. 436, 132 N.Y.S.2d 392 (1954); Wolder's Estate, 28 Pa. D. * C. $2 d$ 51, 53 (Orphans' Ct. 1962). See also In.re Oflinger, 28 Misc. $2 d$ 633, 215 N.Y.S.2d 642 (Surr. Ct. 1961); In re Doktor, 18 Misc. 2d 223, 183 N.Y.S.2d 60 (Surr. Ct. 1959).

${ }^{39} 31$ C.F.R. § 211.2 (1966).

${ }^{+0}$ See, e.g., In re Bold's Estate, 173 Misc. 545, 549, 18 N.Y.S.2d 291, 295 (Surr. Ct. 1940): Sobko Estate, 88 Pa. D. \& C. 76 (Orphans' Ct. 1954), where the court remarked: 'From such information as is available to us concerning the status of the individual in tbese so-called "Iron Curtain' states, there would appear to be little doubt that these unfortunate people have been enslaved by a vicious government which deprives them of many of the rights enjoyed by the free peoples of the world, including the fundamental right of private ownership of property." $I d$. at 77.

"In re Bold's Estate, 173 Misc. 545, 18 N.Y.S.2d 291 (Surr. Ct. 1940).

"E.g.. In re Volencki, 35 N.J. Super. 351, 114 A.2d 26 (Mercer County Ct.. P. Div. 1955). In another case involving a good deal of expert testimony, the court felt it in order to "take judjcial notice of the wholesale disregard of human and of property rights in the USSR and of the complete lack of morals, as we know them, pervading the operation of the Soviet system. We are satisfied that the recipients might by fraud be represented as receiving these goods and, should the signatures on the receipts be genuine, they might have been obtained by coercion or misrepresentation." Zupko Estate, 15 Pa. D. \& C. 2d 442, 454-55 (Orphans' Ct. 1958). 
finance wars against the United States. ${ }^{43}$ Others have eschewed the possibility of enhancing the financial status of non-democratic nations. ${ }^{4+}$ The degree of judicial invective sometimes surrounding the proceedings under these statutes might indicate that the only objective being fostered by their use was the expression of local disapproval of certain foreign nations. ${ }^{45}$ This uncertain standard of benefit, combined with the possibility of a hostile court, may render the statutory burden of proof placed upon the alien claimant insurmountable.

"E.g.. In re Karban, 118 Cal. App. 2d 240, 257 P.2d 649 (1953), where the court said, "property and money of persons dying in this country should remain here and not be sent to foreign countries and be used in waging a war . . . against the United States." Id. at 244, 257 P.2d at 652. Another court expressed fears that funds remitted to the Soviet Union would be used to sabotage American industry. In re Landau's Estate, 172 Misc. 651, 16 N.Y.S.2d 3 (Surr. Ct. 1939).

In adopting a nonresident alien inheritance statute in 1941, the California legislature appended a "statement of urgency" in order that the act would take effect immediately. This statement recited, in part, that "[a] great number of foreign nations are either at war, preparing for war or under the control and domination of conquering nations with the result that money and property left to citizens of California is impounded in such foreign countries or taken by confiscatory taxes for war uses. . . . Because the foreign governments guilty of these practices constitute a direct threat to the Government of the United States, it is immediately necessary that the property and money of citizens dying in this country should remain in this country and not be sent to such foreign countries to be used for the purposes of waging a war that eventually may be directed against the . . United States." Chaitkin, The Rights of Residents of Russia and its Salellites to Share in Estates of American Decedents, 25 S. CAL. L. REV. 297, 304 n.53 (1952). See also Heyman, The .Nonresident Alien's Right to Succession L'nder the "Iron (urlain Rule." 52 Nw. U.L. Riv, 221, 229 nn.57 \& 58, 234 \& nn.96-99 (1957): Comment, Siate Regulation of . Vonresident Alien Inheritance An Anomoly in Foreign Policy, $18 \mathrm{U}$. Cili. L. RL: 329, 331-33 (1951).

"The concurring opinion in In re Hosova's Estate, 143 Mont. 74, 387 P.2d 305 (1963) expressed regret that "in affirming this decision the writer is knowingly contributing financial aid to a Communist monolithic satellite. fanatically dedicated to the abolishing of the freedom and liberty of the citizens of this nation.

"By reason of self-hypnosis and failure to understand the aims and objectives of the international Communist conspiracy, in the year 1946, Montana did not have statutes to estop us from making cash contributions to our own ultimate destruction as a free nation." $I d$. at $85-$ 86. 387 P.2d at 311 .

In II re Getream, 200 Misc. 543, 107 N.Y.S.2d 225 (Surr. Ct. 195I), the court said that it "would consider sending money out of this country and into Hungary tantamount to putting funds within the grasp of the Communists." Id. at 544, 107 N.Y.S.2d at 226. In another case, the judge took "judicial notice" that "funds transmitted to citizens of [the Soviet Union] are confiscated or diverted by the state or its officials and fail to reach the intended beneficiaries." Sobko Estate, 88 Pa. D. \& C. 76.77-78 (Orphans' Ct. 1954). Sec also Berman, supra note 35, at $257 \& \mathrm{nn} .2 \& 3$.

"One commentator reports that in Pennsylvania, a judge stated at the trial of a case involving a Soviet heir that "[ilf you want to say that I'm prejudiced, you can, because when it cumes to Communism l'm a bigoted anti-Communist." In a California case, the trial judge took "judicial 
Although Clark seemed to foreclose constitutional attack upon such applications of alien inheritance statutes as interfering with federal control of foreign relations, petitioners before the Supreme Court have twice sought to inhibit the zeal of probate judges with arguments based upon the due process and equal protection provisions of the fourteenth amendment. Both appeals involved New York's benefit statute, and both were dismissed for want of a substantial federal question. ${ }^{46}$ However, the second of these cases, Ioannou v. New York, was notable for its dissent in which the author of $\mathrm{Clark}^{47}$ indicated his willingness in light of subsequent events to reexamine the rationale of that case. Arguing that other areas of case law recognize an exclusive federal power over foreign affairs, ${ }^{48}$ the Ioannou dissent implied that the actual effect of the state's reciprocity statute on international affairs was determinative of the constitutional

notice that Russia kicks the United States in the teeth all the time," and told counsel for the Soviet claimant that "I would think your firm would feel it honor bound to withdraw as representing the Russian government." Berman, supra note 35, at n.257 (cmphasis added). See also notes 31,40 \& 44 , supra.

to In re Braier's Estate, 305 N.Y. 148, Il I N.E.2d 424, appeal dismissed sub nomt. Kalmane v. Green, 346 U.S. 802 (1953), presented an issue of procedural due process because of the surrogate's failure to grant a hearing before ordering deposit of inheritance. The New York Court of Appeals found three grounds for its conclusion that there was no denial of due process. First, the court reasoned that a hearing was not necessa. $y$ because the legatee had not been deprived of title to the property under the New York statute. See note 5 supra. Further, since the Consular Section of the Hungarian Legation had raised only issues of law, a hearing on these issues at the appellate level was sufficient to satisfy the mandate of due process. Finally, the court noted that if the legatee could later come forward with proof that conditions in Hungary would allow her to reccive the benefit of the legacy, a hearing would then be granted on the propriety of withdrawing the funds. $I d$. at 159,111 N.E.2d at 428-29.

In In re Marck's Estate, 11 N.Y.2d 740, 181 N.E.2d 456, appeal disnissed sub nom. loannou v. New York, 371 U.S. 30 (1962), the surrogate refused to deliver an estate share assigned by a Czechoslovakian beneficiary to a niece domiciled in London. On appeal to the U.S. Supreme Court, petitioner alleged that due process and equal protection considerations were presented by the New York court's refusal, without a hearing, to give effect to an alleged voluntary assignment by the alien beneficiary. See Boyd, supra note 8 , at 488-89 \& nn.82-83.

"Mr. Justice Douglas authored Clark. the Ioannou dissent, and Zschernig.

"3 The dissent began by recognizing that article $l$, section 10 of the Constitution imposes severe limitations upon the several states' power to affect the foreign relations of the United States, then cited dicta from Supreme Court opinions for the proposition that federal power over forcign affairs is exclusive. loannou v. New York, 37 I U.S. 30 (1962) (Douglas, J., dissenting). See notes 22-24 supra.

The dissent further maintained that other areas of law suggest that foreign policy can be shaped solely by the federal government: "Our courts will not inquire into the validity of an act of a recognized foreign state (Oetjen v. Central Leather Co., 246 U.S. 297 [1917]). . . . Likewise, a foreign country is immune from suit for injuries caused in its commercial 
issue in Clark, stating that the latter case did not insulate the alien inheritance statutes from challenge under the exclusive federal foreign relations power when the statutes did, in practice, "affect international relations in a persistent and subtle way." "49

The recent case of Zschernig $v$. Miller ${ }^{50}$ provided the Supreme Court with a satisfactory vehicle for reevaluating the Clark position. In Zschernig the East German heirs of an Oregon intestate chose not to show, under Oregon's hybrid statute, that Americans were accorded reciprocal inheritance rights by East Germany and could receive payment from East German estates, and that East German heirs would receive the benefit, use or control of American estate shares." Rather, the heirs proceeded entirely under federal law, arguing that the 1923 Treaty of Friendship, Commerce, and Consular Rights with Germany ${ }^{52}$ remained effective despite the post-World War 11 partition of that country, and thus that the treaty's clause regarding alien inheritance of real estate partially preempted state law. Further, the heirs contended that the Oregon statute was unconstitutional $^{53}$ since, in practice, its impact upon international

transactions (Berizzi Bros. Co. v. The Pesaro, 271 U.S. 562 [1925]). . . . But, if the Executive Department of the Federal Government indicates its views on whether immunity should be allowed, those views will control. Republic of Mexico v. Hoffman, 324 U.S. 30 [1944]. $"$ ld. at 31-32 (Douglas, J., dissenting).

437 I U.S. at 32 (Douglas, J., dissenting).

¿ 389 U.S. 429 (1968).

"The provisions of the statute are:

"(I) The right of an alien not residing within the United States or its territories to take either real or personal property or the proceeds thereof in this state by succession or testamentary disposition, upon the same terms and conditions as inhabitants and citizens of the United States, is dependent in each case: (a) Upon the existence of a reciprocal right upon the part of citizens of the United States to take real and personal property and the proceeds thereof upon the same terms and conditions as inhabitants and citizens of the country of which such alien is an inhabitant or citizen; (b) Upon the right of citizens of the United States to receive by payment to them within the United States or its territories money originating from the estates of persons dying within such foreign country; and (c) Upon proof that such foreign heirs, distributees, devisees or legatees may receive the benefit, use or control of money or property from estates of persons dying in this state without confiscation, in whole or in part, by the governments of such foreign countries.

"(2) The burden is upon such nonresident alien to establish the fact of existence of the reciprocal rights set forth in subsection ( 1 ) of this section.

"(3) If such reciprocal rights are not found to exist and if no heir, devisee or legatee other than such alien is found eligible to take such property, the property shall be disposed of as escheated property." ORE. Rev. Stat. \$§ $111.070(1)-(3)$ (1967).

" Dec. 8, 1923, 44 Stat. 2132, T.S. No. 725 . See note 14 supra.

s3 The dual thrust of the heirs' major constitutional argument was responsive both to Clark 
affairs was a substantial interference with the exclusive federal foreign relations power. ${ }^{54}$ By offering no proof under the Oregon statute, the Zschernig plaintiffs paradoxically had to rely upon judicial practices in prior cases to substantiate their major constitutional contention that state court assessments of the quality of various rights in foreign countries could adversely affect foreign relations." Accepting the heirs' treaty argument, the Oregon Supreme Court allowed inheritance of the realty by the German heirs. ${ }^{56}$ However, since the heirs had offered no proof under the alien inheritance statute and because the Oregon court believed their constitutional attack to be foreclosed by Clark, the state court held that the personalty must escheat. ${ }^{57}$

Accepting the Oregon Supreme Court's treaty ruling, ${ }^{s *}$ Zschernig's heirs nevertheless sought review in the U.S. Supreme Court of their constitutional challenge to the Oregon statutory scheme. In contradistinction to its approach in Clark, the Court on appeal in Zschernig considered whether, even in the absence of conflicting executive or congressional action, the constitutional grant of foreign affairs powers to the national government carried with it an implied negative on certain types of state activity. The

and Ioannou. On the one hand the heirs sought to demonstrate that Oregon's law, in the light of its judicially-stated purpose to induce foreign nations to guarantee inheritance rights to Americans, see note 26 supra, was "tantamount to the State of Oregon proposing to the nations of the world a compact, an agreement that they conform their inheritance laws to Oregon's. . . Brief for Appellant at 59, Zschernig v. Miller, 389 U.S. 429 (1968); see Clark v. Allen, 331 U.S. 503, 517; text at notes 10-15 supra. In chronicling judicial intemperance under the Oregon statute, appellant further emphasized that, as of the date of Clark. none of the offending judicial practices had occurred. Brief for Appellant at 62, Zschernig v. Miller, supra; cf. loannou v. New York, 371 U.S. at 33 (Douglas, J., dissenting). See text at note 15 supra.

"See note 24 supra.

" Brief for Appellant at 25-64, Zschernig v. Miller, 389 U.S. 429 (1968).

\$6 243 Ore. 567, 591, 412 P.2d 781, 793 (1966).

${ }^{57}$ Id. at 587-88, 412 P.2d at 791 .

"Filing as amicus curiae, the Solicitor General urged that Clark's construction of the 1923 Treaty with Germany be reversed so as to allow foreign citizens to inherit personalty as well as realty from American estates. Brief for the United States as Amicus Curiae at 5-6, Zschernig v. Miller, 389 U.S. 429 (1968). The Government took this position because identical or very similar provisions are found in ten treaties presently in force. Brief for the United States as Amicus Curiae at nn.3 \& 4, Zschernig v. Miller, supra. Thus, the Court was presented with a possible non-constitutional basis for achieving the same result. Zschernig v. Miller, supra at 443 (Harlan, J., concurring); $c$ f. Ashwander v. T.V.A.. 297 U.S. 288, 347 (1936) (Brandeis, J., concurring); Light v. United States, 220 U.S. 523 (1911); Siler v. Louisville \& N.R.R., 213 U.S. 175 (1909). The majority of the Court, however, declined this invitation to base its holding on non-constitutional grounds. 389 U.S. at 432. 
Zschernig majority found that various state courts had, in prior cases, made minute inquiries into the administration of foreign legal systems, ${ }^{59}$ the credibility of foreign diplomatic statements, ${ }^{60}$ and the quality of "rights" secured by foreign laws." Maintaining that such actions must affect international relations "in a persistent and subtle way,"62 the majority ruled the Oregon statute unconstitutional because of its capacity to impair the power of the national government to deal with foreign affairs. ${ }^{63}$ In so holding, the Zschernig Court distinguished rather than overruled Clark on the basis that the Oregon statute as construed would have "more than "some incidental or indirect effect in foreign countries." "'64

By distinguishing Clark, Zschernig allows some degree of continued vitality for the alien inheritance statutes now enacted. The Court undoubtedly wanted to avoid the implication that reciprocity was an improper basis for determining the rights of aliens or that state courts could not read, construe and apply foreign law. ${ }^{65}$ Indeed, the Court suggests that accepting as conclusive proof of reciprocity the statement of a foreign ambassador that reciprocal rights exist in his nation would still be a proper mode of procedure under an alien inheritance statute. ${ }^{66}$ However, the Court's broad gauge assault on any state activities which could potentially embarrass the federal government in the conduct of foreign relations ${ }^{67}$ makes it very difficult

"9 389 U.S. at 433-34, 436-37, citing State Land Bd. v. Rogers, 219 Ore. 233, 347 P.2d 57 (1959).

389 U.S. at 434. 436, cining In re Krachler, 199 Ore. 448, 263 P.2d 769 (1953).

M 389 U.S. at 434, 439-40, citing In re Krachler, 199 Ore. 448, 263 P.2d 769 (1953).

o: 389 U.S. at 440.

${ }^{6} / d$. at 441 .

${ }^{64} \mathrm{Id}$. at 434 (emphasis added). See text at notes 81-82 infra.

" "State courts, of course, must frequently read, construe, and apply laws of foreign nations. It has never been seriously suggested that state courts are precluded from performing that function. . . . Id. at 433.

so $I d$. at 433 n.5. For a case in which a court applying a benefit statute accepted the certificate of the Russian ambassador that citizens of that country would receive the benefit, use and control of an American estate share, see $I n$ re Alexandroff's Estate, 61 N.Y.S.2d 866 (N.Y. County Sur. Ct. 1945).

"The variety of characterizations indulged by the majority opinion obscures the precise gravamen of a constitutional challenge under the Zschernig doctrine. The court noted that several criteria have been employed by Oregon courts in applying their alien inheritance statute, seemingly questioning the propriety of each: (1) whether aliens under the law of their homeland have enforceable "rights" as we know them, 389 U.S. at 436-37, 439-40; (2) whether foreign laws contain any element of confiscation, id. at 435; and (3) whether the statements of officials of foreign nations are credible or made in good faith, id. at 436 . Concomitantly, the Court 
to assess the precise limits of a federal court's power to censure state action in the area of inheritance that in any way may affect foreign affairs.

Since the Zschernig Court was primarily concerned with the inheritance statute's potential to impair the effective exercise of the nation's foreign policy, ${ }^{68}$ nothing in the opinion suggests that an actual diplomatic complaint is a necessary concomitant to a finding of unconstitutionality, although the Court did note one instance in which the Oregon statute was the subject of such a complaint. ${ }^{69}$ The presence of an actual complaint seems merely to underscore the Court's judgment that the statute as applied can affect foreign relations. Since the test adopted by the Court requires only a showing of potential impairment of federal power, it may be appropriate for the Court to go beyond the record in the instant case to determine whether such a potential for disruption is inferable from past applications of the challenged statute. ${ }^{70}$ Indeed, all of the evidence of potential impairment of the federal foreign relations power in

maintains that the decisions of the Oregon courts "radiate some of the attitudes of the "cold war," that "foreign policy attitudes . . . and the like are the real desiderata," and implies that Oregon has been "permitted to establish its own foreign policy." Id. at 435, 437, and 44l. Apparently the common objectionable thread running through all these various actions is that each has "a direct impact upon foreign relations and may well adversely affect the power of the central government to deal with those problems." Id. at 441. Whether any single instance of the sundry condemned activities would be a sufficient index of the tendency of a stutute as applied to impair the effective exercise of the nation's foreign policy, or whether it is the cumulative effect of many such instances that renders the statute unconstitutional is not entircly cluar. The latter interpretation is indicated by the Court's statement that "the type of probate law that Oregon enforces affects international relations in a persistent and subtle way." Id. at 440 (emphasis added).

${ }^{\text {s8 }}$ For instance, the Court at one point maintains that the Oregon statute's "great potemial for disruption or embarrassment makes us hesitate to place it in the category of a diplomatic bagatelle." 389 U.S. at 435 (emphasis added). Elsewhere the Court concludes that the statute "has a direct impact upon foreign relations and may" well adversely affect the power of the central government to deal with those problems." Id. at 441 (emphasis added).

${ }^{69}$ The Court noted a letter, written by a State Department adviser to an Orcgon court, which stated: "The Government of Bulgaria has raised with this Government the matter of difficulties reportedly being encountered by Bulgarian citizens resident in Bulgaria in obtaining the transfur to them of property or funds from estates probated in this country, some under the jurisdiction of the State of Oregon. . . ." 389 U.S. at 437 n.7.

${ }^{70}$ Thus, the Court can summarily dismiss the Justice Department's claim that the application of the Oregon statute, in the circumstances of the Zschernig litigation, did not unduly interlere with the conduct of foreign relations, see 389 U.S. at 434 , citing Brief for United States as amicus curiae, p. 6, n.5, since this fact is simply not pertinent to the constitutional inquiry which the Court conducts, namely whether the statute has the potential to impair the exercise of the nation's foreign policy. See note 63 supra. 
Zschernig was derived from prior experience with the statute ${ }^{71}$ since that case at the state court level involved an order of escheat because of the heirs' failure to offer any proof of conditions in East Germany." Moreover, Zschernig implicitly establishes a judicial, rather than an executive, prerogative to make the ultimate determination as to a statute's potential impairment of the federal foreign relations function. ${ }^{73}$ This judicial willingness to undertake an independent factual assessment of matters affecting foreign relations provides an interesting contrast to the Court's approach in Banco Nacional de Cuba v. Sabbatino ${ }^{74}$ where it was similarly concerned with protecting the executive department's prerogative to conduct foreign affairs. In Sabbatino the Court found that Act-of-State cases presented a recurrent factual situation ${ }^{75}$ in which action by the judiciary might hinder diplomatic efforts by the executive department,

"Thus, the Court seems to consider the continued judicial proclivity to allow local foreign policy biases to permeate the decision-making process to be sufficient to infect an entire statute, concededly valid as written, and render it unconstitutional. Apparently, states whose courts have in the past engaged in any of the activities condemned by Zschernig must, either by legisiative or judicial action, affirmatively insure that their statutes cannot be applied in a manner which could impair the capacity of the federal government to conduct foreign affairs.

The California Supreme Court seems to have effectively eliminated one frequent source of friction under the alien inheritance statutes in ruling that state court inquiries into foreign currency regulations are improper because, ". . . to cmbark upon any such adventure would gravely imperil the constitutionality of section 259 by involving our courts in matters of international monetary policy which may be within the exclusive province of federal authority." In re Chichernea, 66 Cal. 2d 83, 105. 57 Cal. Rptr. 135, 150, 424 P.2d 687, 702 (1967).

"See text at note 57 supra.

"Not only did the Court have before it the Justice Department's claim that the Zschernig litigation presented no interference with the conduct of the nation's foreign policy, see note 70 supra, but also a more generalized executive department assessment of the effect of reciprocity statutes: "The Department of State has advised us . . . that State reciprocity laws, including that of Oregon, have had little effect on the foreign relations and policy of this country .... Appellants' apprehension of a deterioration in international relations, unsubstantiated by experience. does not constitute the kind of "changed conditions' which might call for a reexamination of Clark v. Allen." 389 U.S. at $460 \mathrm{n} .29$ quoting Memorandum for United States. p. 5 . In contradistinction to this is the Court's judgment that "-[i]t seems inescapable that the type of probate law that Oregon enforces affects international relations in a persistent and subtle way." 389 U.S. at 440.

`376 U.S. 398 (1964); see Henkin, The Foreign Affairs Power of the Federal Courts: Sabbatino. 64 Colum. L. Rev. 805 (1964).

"A typical Act of State case involves the confiscation of private property coincident with a revolution in a foreign land. See, e.g., Banco Nacional de Cuba v. Sabbatino, 376 U.S. 398 (1964); Oetjen v. Central Leather Co., 246 U.S. 297 (1918); Republic of Iraq v. First National City Bunk, 353 F.2d 47 (2d Cir. 1965), cert. dented, 382 U.S. 1027 (1966). If jurisdiction can be obtained in a court, the ensuing controversy between claimants under the confiscating 
and consequently announced a federal rule that judges should not examine the validity of property confiscation by a foreign government within its own territory. ${ }^{76}$ The effect of this doctrine was to force parties aggrieved by such a foreign confiscation to seek their exclusive remedy with the executive branch. Thus, Sabbatino's protection for the executive was achieved by way of judicial abstention while Zschernig purports to protect the foreign relations power by marked activism. In general, it may be conceded that the former approach is preferable since the judiciary's role in affecting foreign relations should undoubtedly be a limited one. However, there are vital distinctions between Zschernig and Sabbatino which indicate that the activism of the Zschernig. Court was not inappropriate. The fundamental distinction is that. Zschernig involved the allocation of power between the two sovereignties of our federal system while Sabbatino did not. ${ }^{77}$ Thus, Zschernig's insistence upon an independent judicial assessment of the relevant facts was required by the Court's role as interpreter of the Constitution, while the Sabbatino Court's deference to an executive remedy was permissible because no question of constitutional interpretation was involved in that case. Moreover, from a pragmatic viewpoint, the Zschernig situation may have been one in which the executive branch was incapable of taking effective action since either treaty arrangements with Communist nations or a federal statute governing alien inheritance might encounter substantial domestic political obstacles.

Zschernig represents the first case in which the preemptive effect of the exclusive federal foreign relations power was the sole basis for the Court's decision. ${ }^{78}$ While this might indicate an increased judicial concern with protecting the federal government's power to conduct diplomacy, the possible applicability of the Zschernig doctrine to areas of state action other than alien inheritance statutes ${ }^{79}$ is difficult

government and under the original owners will revolve around the question of the validity of the taking which the foreign regime effected. American courts have traditionally refused to pass on such an issue although the reasons given have varied. Sec A. EHRENZWEIG. I TREATISI U THE CONFLICT OF LAWS $\S 48$ (1962).

76376 U.S. at 428.

" "The text of the Constitution does not require the act of state doctrine: it does not irrevocably remove from the judiciary the capacity to review the validity of foreign acts of state." 376 U.S. at 423. Moreover, implicit in the Sabbatino Court's approach was the view that the Constitution did not require judicial, as opposed to executive. resolution of the issues involved.

"See note 25 supra.

7v See Moore, Federalism and Foreign Relations. 1965 Duke L.J. 248, 3 11-17. 
'to assess due to the Court's almost exclusive concern with describing the operation of the particular type of statute before it. ${ }^{80}$ Indeed, the Zschernig Court characterizes as "remote" the possibility that other forms of litigation will have an effect upon international relations," thus ironically echoing the judgment in Clark that reciprocity statutes would have only "some incidental or indirect effect in foreign countries." Given the debilitation of that position in Zschernig. however, it seems unlikely that one may safely predict the precise limitations of the preemptive effect of the federal foreign relations power solely by characterizing the impact of state action upon foreign affairs as either "direct" or "remote."

\footnotetext{
"See notes 67-68 supra.

" 389 U.S. at 433.

"Clark v. Allen, 331 U.S. 503. 517 (1947).

"Some of the uncertainty inherent in the direct-or-indirect-effect test might be avoided were the Court to adopt a balancing test analogous to that employed to determine the preemptive effect of the commerce clause. Under this approach, the judiciary could closely scrutinize the nature of the state interests purportedly advanced by the regulation in question, weighing that interest against the national governmental interest in controlling foreign affairs, and assessing the possibilities of interference stemming from the state enactment. See Moore, supra note 79, at 299-301. By focusing on whether any legitimate state interests are actually served by the regulation, the judiciary might avoid placement of undue emphasis upon the largely speculative assessment of the statute's potential effect on foreign alfairs. Thus, in reviewing a reciprocity statute, it might be determined that the real purpose of the act is to induce foreign nations to alter their inheritance policies toward American citizens, a goal outside the scope of state power under the theory that the national executive is the sole constitutional representative in foreign affairs. Likewise, an interest in preventing funds from being transmitted to disfavored or unfriendly foreign countries under benefit statutes should arguably fall. Finally, a careful analysis of the state's interest in allowing inheritance to some heirs while denying it to others on the basis of nationality and related factors may give rise to an effective equal protection argument that the states have no legitimate interest in making such a distinction, the asserted state interests being incompatible with national supremacy in the foreign relations area. Sice generally. Boyd, The Invalidity of State Statutes Governing the Share of . Tonresident thiens in Decedents' Latates. 5 I (ji:O. L.J. 470, 485-92 (1963).
} 